\title{
Editorial
}

\section{Islam, World Peace, and the Discourse of Revenge}

Every time anger and frustration take over the human spirit, reason and rational thinking fade into the background. High emotions cloud minds, subvert justice, and undermine peace. In the absence of reason, new terminology takes hold. The discourse on terrorism that rages today in the aftermath of the horrific terrorist strikes on New York and Washington is ripe with emotions triggered by sinister and apocalyptic attacks on unarmed and non-combatant civilians. On television and radio talk shows across the United States, countless self-acclaimed experts on terrorism counsel that we strike back against a host of countries suspected of supporting terrorism. Statements from the White House have been more balanced and measured, but the theme is the same: an all-out war on terrorism.

Terrorism we must fight, and we must fight with determination and vigor. But for the fight to be effective, it must be carried on according to fair rules, and must aim at the real target. An effective war on terrorism requires two elements. First, we must have a clear understanding of the sources of the anger and frustration that lies at the root of global terrorism and a clear definition of what constitutes a terrorist act. Second, we must have a clear vision of a global society based on the universal principles of equal freedom and mutual respect. A war on terrorism that employs moral themes but advances the narrow interests of a privileged few can bring more evil than good, as it is likely to result in harming innocent bystanders.

Judging by the discourse of revenge and war, we have a long way to go before true understanding and clear vision come to bear on the strategic thinking of political leaders. This puts an extra burden on intellectuals and scholars. Scholars of all regions, religions, and persuasions are called upon more than ever before to bring reason and enlightenment to a world filled with emotion and ignorance. 


\section{Anguish over "Why?"}

To understand the extent to which our current political discourse is insufficient and found lacking in approaching the serious task of eliminating terrorism and bringing about the world peace so essential for the globalizing world of today, let us look briefly at the way the "why?" question concerning the rise of global terrorism is being handled.

In a televised address to a joint session of Congress, President Bush raised the very question that continues to puzzle Americans: Why would anyone want to harm America? What motivates nineteen Middle Eastern men to shatter the lives of several thousand civilians, and to bring pain, grief, and anguish to even greater numbers of their families, friends, and countrymen? What in the world would produce the degree of anger, hate, and hostility we all have seen explode in front of our eyes, as we sat watching with bewilderment and horror the two civilian jetliners crash into the World Trade Center's twin towers?

"Why do they hate us?" Bush asked in his statement to Congress. His answer was short and straightforward: "They hate what they see right in this chamber: a democratically elected government. Their leaders are self-appointed. They hate our freedoms: our freedom of religion, our freedom of speech, our freedom to vote and assemble and disagree with each other." Bush's answer, while containing elements of truth, seems to be lacking on several important points.

It is true that the radical groups who attacked the United States have little appreciation of freedom and democracy. Most peoples in the Middle East have had no experience in recent memory of freedom of speech and assembly, and no experience of true and functional democracy. However, while radicals, who constitute a fraction of Middle Eastern societies, are involved in destructive endeavors that are bound to shake the foundation of world peace, the bulk of the people in the Middle East yearn for an open political system, in which freedom of religion, speech, and assembly are part and parcel of their political experience. It is also true that selfappointed leaders, who rely on military force to keep their populations in check, rule most regimes in the Middle East.

It is equally true that Americans hold the values of freedom and democracy in high esteem. Americans have been vigilant in ensuring that the freedom and democracy they have inherited from the founders of this great nation are not usurped or taken away. The combination of political and religious freedoms on the one hand, and the accountability of elected 
officials on the other, give this country an edge over others, and attract every year hundreds of thousands of creative and hardworking people who find in America's freedom a atmosphere conducive to improving their personal lives and enriching the life of their community and adopted country.

\section{National Interest vs. Human Rights}

The sad fact, which President Bush has overlooked, is that in many parts of the world, and particularly in the Middle East, America is associated not with freedom and democracy but with suppressive and autocratic regimes. For the last fifty years, successive United States governments have stood behind self-appointed leaders, providing them with financial and military support as well as security and political guidance. Far from being viewed as the guardian of freedom and democracy, the United States is often seen to be the power behind military regimes and unscrupulous dictators.

The United States' engagement in Iran is a case in point. In the fifties, the United States Central Intelligence Agency was directly involved in engineering the coup $d^{\prime \prime}$ tat that removed the democratically elected government of Mohammed Musadeq and installed the regime of the Shah in 1954. Despite his abuse of the civil liberties of his people, and his extensive use of state security forces to suppress critics and opposition, the Shah continued to receive the blessing of American leaders. President Carter, who insisted that the United States' foreign policy must be informed by American concerns over human rights, praised the Shah during a visit shortly before the latter was ousted by the Islamic revolution. The United States later took an active part in arming Saddam Hussein in a bid to topple the revolutionary government in Tehran. To ensure the cooperation of the Iraqi military government, the Reagan Administration kept silent when Saddam used chemical weapons against Iranians as well as against the Kurdish opposition in Northern Iraq. It was only when the belligerent Saddam turned his newly acquired military strength against the oil-rich Gulf countries that he was declared a renegade.

The failure of successive United States' administrations to project clear and sustained interests in freedom and democracy can be seen in the United States' position vis--vis the Israeli-Palestinian conflict. For decades, Arabs and Muslims watched the Israeli government expand its territories at the expense of its Arab neighbors. Israel was allowed to occupy the West Bank and Gaza, the Golan Heights, and South Lebanon with the tacit approval 
and blessing, and occasionally with the open support, of the United States government, in spite of successive UN resolutions and clear violations of international law.

Over the past year, Middle Easterners have watched countless pictures: of Israeli soldiers shooting at rock-throwing Palestinian kids, of US-made Apaches, designed to destroy tanks, used for assassinating Palestinian activists, and of US-made tanks and rocket launchers used to suppress the Palestinian Intifada.

\section{Singling out Islam}

The president, along with several American leaders, counseled against targeting Muslim Americans, and went out of his way to disassociate Islam and terrorism. Still many, particularly in the media, continue to make both subtle and direct attacks on Islamic beliefs and values. Among all religions, Islam has been singled out by media groups, and unfairly blamed for acts of terror carried out by Muslim groups. The blame is frequently subtle, articulated through the old and primitive instrument of "guilt by association." It often takes the form of using Islam as an adjective to describe terrorism, hence the catch phrase "Islamic terrorism." Alternatively, Islamic symbols and sounds - e.g., mosque, prayer, call to prayer, etc.-are played in the background every time a terrorist act is reported. Occasionally, the blame is laid at the doorstep of Islam by "experts" on terrorism, a la Daniel Pipes and Steven Emerson, who find it convenient to point fingers at all practicing Muslims in order to push their narrow political agenda.

The efforts to blame Islam for terrorism are not only baseless and erroneous, but are unmistakably malicious and ill-intended. Islam, like many religious traditions, stresses charity, mercy, and compassion. Historically, Islam is recognized for its tolerance toward other religions, even when bigotry and intolerance were widely accepted and practiced in medieval times. But like other religious traditions, Islam recognizes the right of peoples to fight aggression, even though it puts a higher premium on forgiveness. Reciprocity, an eye for an eye, is found in Christianity and Judaism as well. Further, like other religions, Islamic texts contain statements that emphasize forgiveness and peace, along with others that permit the use of force for fighting back against aggression and for achieving a just peace. 
In Deuteronomy, the fifth book of the Torah, Moses narrates to the Israelites a fiery message from God as they prepare to enter the promised land: "I will make mine arrows drunk with blood, and my sword shall devour flesh; and that with the blood of the slain and of the captives, from the beginning of revenge upon the enemy."

Likewise, the Gospels contain texts that call for the use of force to avenge the rights of people and to punish the unjust. In the Gospel of Matthew, a statement attributed to Jesus reads: "Think not that I am come to bring peace on earth. I came not to bring peace, but the sword."

A partial and out-of-context reading of religious texts, combined with a desire to reciprocate against real or perceived injustice, may lead misguided individuals and radical groups to commit atrocities in the name of religion and justice. Muslim scholars and leaders must speak against using Islam and Islamic doctrines to undertake acts rooted in political ambition or frustration.

By the same token, media organizations have the duty to present a balanced picture of Muslim society and faith, rather than feeding on the frenzy of bigotry and stereotyping. The media more often than not focuses on the eccentric and extraordinary, and as such brings distorted pictures of Middle Eastern realities. Rather than showing that radical Islamic groups stand on the fringe, outside mainstream society, the media reverse the picture by projecting radicalism and extremism as the norm in the Middle East. The sight of a handful of Palestinian youths celebrating an American calamity is newsworthy, but a demonstration by thousands of sympathetic Arabs is not.

\section{Global Peace and American Leadership}

The recent tragic events put the world in general, and the United States in particular, at a crossroads. We have the choice of marching forward toward global peace, rooted in rules of equitable law, and fairly administered to all, the strong and the weak, the far and the near; or of immersing ourselves in empire building, in which the strong conquer and dominate everyone else.

The United States is in a unique position-culturally, economically, and politically - to lead the world in either direction. And given the choice, I am confident that Americans would choose global peace over world empire. But for America to make the right choice, political leaders, as well as the leaders of public opinion, have to play a pivotal role in helping the public make the right move by choosing American values over America's 
narrow and short-term interests. It is true that lending support to corrupt governments makes it a bit easier, in the short run, for the United States to influence the foreign and domestic policies of these governments. In the long run, however, a foreign policy oblivious to moral standards is bound to corrupt American politics. The terrorist attacks on New York and Washington have brought forth loud voices calling for compromising the precious freedom Americans enjoy in exchange for a false sense of security.

Terrorism can be fought not through military war, but by bringing justice and eliminating the roots of desperation. History, both old and new, is rampant with examples of great powers that wasted their resources, and hence lost their privileged positions in the world, by improving war apparatus and overlooking the need for justice.

While fighting terror and strengthening the foundation of world peace is the concern of all enlightened peoples throughout the world, American scholars and intellectuals have greater responsibility in leading the rest of the world in promoting global justice and peace. To do so, they must put the requirements of right and justice over narrow interests and temporary privileges. They must speak out and oppose aggression, the killing of unarmed civilians, and the use of violence for silencing opposition and suppressing dissent the world over. 